\title{
A New Diagnostic System for Detection of 'Candidatus Liberibacter asiaticus' Infection in Citrus
}

Lianming Lu, Zhejiang Citrus Research Institute,Taizhou, 318020, China; Baoping Cheng, Plant Protection Research Institute, Guangdong Academy of Agricultural Sciences/Guangdong Provincial Key Laboratory of High Technology for Plant Protection, Guangzhou 510640, China; Jinai Yao, Plant Protection Research Institute, Fujian Academy of Agricultural Sciences, Fuzhou, 350013, China; Aitian Peng, Plant Protection Research Institute, Guangdong Academy of Agricultural Sciences/Guangdong Provincial Key Laboratory of High Technology for Plant Protection; Danchao Du, Zhejiang Citrus Research Institute; Guocheng Fan, Fruit Research Institute, Fujian Academy of Agricultural Sciences, Fuzhou, 350013, China; and Xiurong Hu, Liping Zhang, and Guoqing Chen, Zhejiang Citrus Research Institute

\begin{abstract}
Lu, L., Cheng, B., Yao, J., Peng, A., Du, D., Fan, G., Hu, X., Zhang, L., and Chen, G. 2013. A new diagnostic system for detection of 'Candidatus Liberibacter asiaticus' infection in citrus. Plant Dis. 97:1295-1300.

In this study, two polyclonal antibodies were produced against the Omp protein of 'Candidatus Liberibacter asiaticus'. First, omp genes were sequenced to exhibit $99.9 \%$ identity among 137 isolates collected from different geographical origins. Then, two peptides containing the hydrophobic polypeptide-transport-associated (POTRA) domain and $\beta$ barrel domain, respectively, were identified on Omp protein. After that, these two peptides were overexpressed in Escherichia coli and purified by affinity chromatography to immunize the white rabbits. Finally, the antiserum was purified by affinity chromatography. The two Omp antibodies gave positive results (0.454 to $0.633,1: 1,600$ dilution) in

enzyme-linked immunosorbent assay against ' $\mathrm{Ca}$. L. asiaticus'infected samples collected from different geographical origins but revealed negative results against other pathogen-infected, nutrient-deficient and healthy samples. The antibody against the POTRA domain of Omp protein could detect ' $\mathrm{Ca}$. L. asiaticus' in $45.7 \%$ of the symptomatic samples compared with a $56.2 \%$ detection rate with a polymerase chain reaction assay. These new antibodies will provide a very useful supplement to the current approaches to ' $\mathrm{Ca}$. L. asiaticus' detection and also provide powerful research tools for tracking distribution of this pathogen in vivo.
\end{abstract}

Citrus greening (huanglongbing [HLB]) is one of the most destructive diseases that affect citrus husbandry in many parts of the world (Asia, North America, South America, and Africa) $(5,7)$. The causal agents of this disease are three 'Candidatus Liberibacter spp.', which are gram-negative, phloem-limited bacteria. The Asian form, 'Candidatus Liberibacter asiaticus' is widespread in all HLB-affected countries (including the United States, Brazil, and several Asian countries) outside Africa $(1,22,25)$, and its vector is a phloem-feeding citrus psyllid, Diaphorina citri Kuwayama $(23,38)$. At present, there is no effective control method to manage this disease, and no cultivars resistant to the pathogen are available. Therefore, rapid diagnosis and immediate removal of the infected trees are among the most general practices used to control the HLB. Polymerase chain reaction (PCR) systems have been used for molecularly detecting HLB pathogens (35). However, PCR methods sometimes provide contradictory results, even within the same set of samples, because of the uneven distribution of the pathogen in citrus trees and because of the inherent nature of PCR assays (sensitive to contamination, nontarget amplification, and so on; 19). There-

Corresponding authors: G. Chen, E-mail: chenguoqing0576@163.com; and B. Cheng, E-mail: Chengbaoping2011@ gmail.com

L. Lu, B. Cheng, and J. Yao contributed equally to this work.

* The $e$-Xtra logo stands for "electronic extra" and indicates that 2 supplementary tables and 4 supplementary figures are available online.

Neither the entire article nor any part of its content has been published or has been accepted elsewhere. It has not been submitted to any other journal.

Accepted for publication 25 March 2013.

http://dx.doi.org/10.1094/PDIS-11-12-1086-RE

(C) 2013 The American Phytopathological Society fore, developing detection methods that improve HLB diagnosis is a pressing need in the citrus industry.

The enzyme-linked immunosorbent assay (ELISA) is an antibodybased detection method that is not only highly sensitive but also highly target specific (31). To date, several (more than 10) monoclonal antibodies (MAs) have been developed against ' $C a$. L. asiaticus' using extracts of infected periwinkle phloem tissues as immunogens. However, this has been difficult because of the noncontinuously cultured nature of the ' $\mathrm{Ca}$. L. asiaticus' bacteria $(14,21,25)$. Additionally, three more MAs were obtained using antigenic proteins extracted by affinity chromatography from infected periwinkle phloem tissues. However, these procedures are very complex and the productivity of antigens is very low (11). One other drawback with these preparation methods is that they are very susceptible to contamination with host plant proteins that can cause a lack of specificity in the antibodies developed using these antigenic preparations. What's more important, all these antibodies are too specific for the strains used for antigen preparation and often failed to react with HLB pathogen isolates from other geographical origins. This is probably because their antigenic proteins may not have a high degree of structural conservation among different isolates (13). These shortcomings are great barriers for these special antibodies to become practical HLB diagnosis reagents. Hence, antibodies which are easy to produce and have broader specificity range are needed.

Gradually, more and more new genes of HLB pathogens have been obtained (26). Also, the complete genome of ' $\mathrm{Ca}$. L. asiaticus' is now available (8). This progress has provided opportunities to explore for new candidate antigens. Omp protein is believed to be an outer membrane protein and may act as a surface antigen of the pathogen. However, outer membrane proteins usually have a very complex structure and, also, they are very difficult to express in Escherichia coli (30). Bioinformatics approaches to the prediction of protein structures and other means of detailed structural analysis of Omp protein may help us identify suitable sequence fragments for high-level expression in E. coli that can facilitate the production of antigen. 
In this study, two highly sensitive and specific polyclonal antibodies were produced against the polypeptide-transport-associated (POTRA) domain and $\beta$-barrel transmembrane domain of Omp protein with the aid of bioinformatics analysis. These Omp antibodies can be used to overcome the shortcomings of currently used antibodies. They can detect HLB pathogen strains from different geographical origins and, thus, improve the current approaches to 'Ca. L. asiaticus' detection and HLB diagnosis.

\section{Materials and Methods}

Plant materials. Citrus shoots infected by ' $\mathrm{Ca}$. L. asiaticus' isolates with variation in Omp sequences were collected from Thailand, France, and five provinces in China. The sample descriptions are provided in Tables 1 and 2. The collected materials were grafted into healthy citrus seedlings in the greenhouse. After the inoculated seedlings showed typical HLB symptoms, ' $C a$. L. asiaticus' was transmitted to healthy periwinkles by dodders for preservation. (These plants were grown in a greenhouse at $25^{\circ} \mathrm{C}$ during 12-h days with illumination intensity 10,000 lux and at $20^{\circ} \mathrm{C}$ for 12 -h nights).

The citrus plant collections from China in Tables 3 and 4 were visually examined and HLB-symptomatic samples were collected during November to April 2009 and 2010 from randomly selected commercial citrus groves located in China's Zhejiang, Guangdong, Fujian, Guangxi, and Jiangxi Provinces. Samples were stored at $4^{\circ} \mathrm{C}$ and processed within $48 \mathrm{~h}$. Nutrient-deficient-symptomatic citrus plants were detected as described previously $(10,27,28,33)$. We used PCR methods for detection of Citrus tristeza virus, Citrus tatter leaf virus, Citrus exocortis viroid, Satsuma dwarf virus, and ' $C a$. L. asiaticus', as described in earlier reports $(12,16-18,20)$. Mixed infected samples were not included in our study.

PCR amplification of the omp gene. The omp gene (2,422 bp) was amplified with primers OMP5/OMP3 (5'-GATGATAGGTGC ATAAAAGTACAGAAG-3'/5'-AATACCCTTATGGGATACAAAAA$\left.3^{\prime}\right)$ for omp gene sequencing. The 5'-terminal POTRA domain (921-bp fragment) of the omp gene was amplified with primers OMPN5/OMPN3 (5'-AGCGGATCCCAATTGAAGATGATAGTT CGC-3' $15^{\prime}$-AGCAAGCTTTTACACATAATCGGATACATCA$\left.3^{\prime}\right)$ and the $3^{\prime}$-terminal $\beta$-barrel transmembrane domain (1,047-bp fragment) of the omp gene was amplified with primers OMPC5/ OMPC3 (5'-AGCGGTACCAGCGCTGGTTCTGTAGGTATAGC-
3'/5'-AGCAAGCTTTTACATGCGATTACCTATACG-3'). The 2,364 bp full-length omp gene was amplified with primers OMPY1/ OMPY2 (5'-CGTCGACTCGTGCATAAAAGTACAGAAGAT-3'l 5'-TGCGGCCGCCTACATGCGATTACCTATAC-3') for Omp prokaryotic expression. The PCR reaction mixture $(25 \mu \mathrm{l})$ contained $10 \mathrm{mM}$ Tris- $\mathrm{HCl}, 2.5 \mu \mathrm{l}$ of $10 \times$ reaction buffer, $0.2 \mathrm{mM}$ dNTPs, 1.5 $\mu \mathrm{l}$ of each primer $(10 \mu \mathrm{M}), 1 \mathrm{U}$ of Taq DNA polymerase, and $1 \mu \mathrm{l}$ of template DNA. The amplification conditions included initial denaturation at $94^{\circ} \mathrm{C}$ for 5 min followed by 35 thermocycles, each consisting of denaturing at $94^{\circ} \mathrm{C}$ for $1 \mathrm{~min}$, annealing at $55^{\circ} \mathrm{C}$ for 1 min, and extending at $72^{\circ} \mathrm{C}$ for 2 to 3 min. Finally, an extension of $72^{\circ} \mathrm{C}$ for $10 \mathrm{~min}$ was included. PCR products were examined by electrophoresis on $1 \%$ agarose gel prestained with GelRed nucleic acid stain (Biotium).

Plasmid construction and recombinant protein preparation. The PCR products amplified with primers OMPY1/OMPY2 were digested with SalI/NotI; then, the purified products were inserted into prokaryotic expression vector pET-32a, pGEX-4T-1, or pIGH3 (GL Biochem Ltd.). These vectors have a T7 promoter or tac promoter, and also fuse His-tag or GST-tag to the N terminal of target proteins for purification purpose. The PCR products amplified with primers OMPN5/OMPN3 and OPMC5/OMPC3 were digested with BamHI/HindIII and KpnI/HindIII. respectively. The enzymedigested products were purified and then inserted into a prokaryotic expression vector pIGH3 to construct pIGH3-OMP-N and pIGH3-OMP-C recombinant vectors. The recombinant vectors were transformed into E. coli strain BL21 (DE3) and cells were cultivated at $37^{\circ} \mathrm{C}$ in $300 \mathrm{ml}$ of Luria-Bertani liquid medium containing ampicillin at $50 \mu \mathrm{g} / \mathrm{ml}$. At an optical density at 600 $\mathrm{nm}\left(\mathrm{OD}_{600}\right)$ of 0.5 to 0.6 , isopropyl-thio-galactopyranoside was added to induce expression of the recombinant proteins. After an additional $4 \mathrm{~h}$ of incubation at $37^{\circ} \mathrm{C}$, cells were harvested and disrupted by ultrasound. Then, the inclusion bodies were washed three times in washing buffer I (0.5\% Triton X-100, $50 \mathrm{mM}$ Tris$\mathrm{HCl}$, and $10 \mathrm{mM}$ EDTA, $\mathrm{pH} 8.0$ ), then washed three times in washing buffer II (2 M urea, $50 \mathrm{mM}$ Tris- $\mathrm{HCl}$, and $10 \mathrm{mM}$ EDTA, $\mathrm{pH}$ 8.0). The sediment was dissolved in buffer III (5 mM imidazole, $0.5 \mathrm{M}$ sodium chloride, $20 \mathrm{mM}$ Tris, and $8 \mathrm{M}$ urea, $\mathrm{pH}$ 7.9) at $4^{\circ} \mathrm{C}$ for about $4 \mathrm{~h}$. The insoluble materials were removed by centrifugation at $12,000 \times g$ for $20 \mathrm{~min}$ at $4^{\circ} \mathrm{C}$. The recombinant Omp proteins fused with His-tag were purified from

Table 1. Enzyme-linked immunosorbent assay (ELISA) detection of citrus samples infected by 'Candidatus Liberibacter asiaticus' isolates with sequence variation in Omp proteins ${ }^{\mathrm{a}}$

\begin{tabular}{lcccccc}
\hline & \multicolumn{6}{c}{ OD $_{\text {450 }}$ values of ' $\boldsymbol{C a}$. L. asiaticus'-infected citrus samples } \\
\cline { 2 - 7 } Antibody & ZJ & FJ & GX & GD & JX & CK \\
\hline OMP-N & $0.495 \pm 0.057$ & $0.552 \pm 0.105$ & $0.476 \pm 0.076$ & $0.538 \pm 0.032$ & $0.519 \pm 0.063$ & $0.146 \pm 0.033$ \\
OMP-C & $0.468 \pm 0.043$ & $0.483 \pm 0.046$ & $0.452 \pm 0.092$ & $0.527 \pm 0.016$ & $0.454 \pm 0.054$ & $0.169 \pm 0.008$ \\
PA & $0.692 \pm 0.102$ & $0.670 \pm 0.036$ & $0.787 \pm 0.117$ & $0.748 \pm 0.032$ & $0.640 \pm 0.062$ & $0.307 \pm 0.052$ \\
\hline
\end{tabular}

${ }^{a}$ Citrus samples in this table were infected with ' $\mathrm{Ca}$. L. asiaticus' isolates with variation in Omp sequences. They were collected from China's Zhejiang (ZJ), Fujian (FJ), Guangxi (GX), Guangdong (GD), and Jiangxi (JX) Provinces. They were tested by indirect ELISA. Antibodies used in ELISA were prepared against OMP-N and OMP-C (1:1,600 dilution) or against purified ' $C a$. L. asiaticus' (PA, 1:800 dilution). Numbers in the table are mean coefficient of optical absorption at $450 \mathrm{~nm}$ in ELISA with the negative control of healthy sample (CK). Optical density at $450 \mathrm{~nm}\left(\mathrm{OD}_{450}\right.$; sample)/OD $450(\mathrm{negative}$ control) $>2.1$ is considered a positive result. Results are representative of three independent experiments with similar results; \pm indicates standard deviation.

Table 2. Enzyme-linked immunosorbent assay (ELISA) detection of periwinkle samples infected by 'Candidatus Liberibacter asiaticus' isolates with sequence variation in Omp proteins ${ }^{\mathrm{a}}$

\begin{tabular}{lcccccccc}
\hline & \multicolumn{7}{c}{ OD $_{\text {450 }}$ values of 'Ca. L. asiaticus'-infected periwinkle samples } \\
\cline { 2 - 9 } Antibody & \multicolumn{1}{c}{ TH } & \multicolumn{1}{c}{ FR } & \multicolumn{1}{c}{ ZJ } & \multicolumn{1}{c}{ FJ } & \multicolumn{1}{c}{ GX } & GD & JX & CK \\
\hline OMP-N & $0.683 \pm 0.047$ & $0.645 \pm 0.034$ & $0.685 \pm 0.040$ & $0.664 \pm 0.039$ & $0.618 \pm 0.031$ & $0.627 \pm 0.077$ & $0.637 \pm 0.048$ & $0.147 \pm 0.013$ \\
OMP-C & $0.585 \pm 0.050$ & $0.580 \pm 0.027$ & $0.62 \pm 0.079$ & $0.589 \pm 0.015$ & $0.527 \pm 0.057$ & $0.537 \pm 0.029$ & $0.521 \pm 0.087$ & $0.153 \pm 0.031$ \\
PA & $0.848 \pm 0.034$ & $0.704 \pm 0.051$ & $0.658 \pm 0.029$ & $0.696 \pm 0.034$ & $0.814 \pm 0.053$ & $0.799 \pm 0.031$ & $0.788 \pm 0.080$ & $0.283 \pm 0.051$ \\
\hline
\end{tabular}

a Numbers in the table are mean coefficient of optical absorption at $450 \mathrm{~nm}$ in ELISA. Abbreviations: Thailand (TH); France (FR); China's Zhejiang (ZJ), Fujian (FJ), Guangxi (GX), Guangdong (GD), and Jiangxi (JX) Provinces; CK, negative control of healthy sample. Optical density at $450 \mathrm{~nm}\left(\mathrm{OD}_{450}\right.$; sample) $/ \mathrm{OD}_{450}$ (negative control) $>2.1$ is considered a positive result. Results are representative of three independent experiments with similar results; \pm indicates standard deviation. 
the soluble phase proteins using a His-Trap FF crude Kit (GE Healthcare) following the instructions of the manufacturer. The recombinant proteins possessing the $\mathrm{N}$-terminal or $\mathrm{C}$-terminal region of Omp protein were dissolved in the supernatant and detected by sodium dodecyl sulfate polyacrylamide gel electrophoresis. The protein concentration was determined by the Bradford assay using bovine serum albumen (BSA) as a standard (6).

Sequence analyses. DNA sequences at National Center for Biotechnology Information databases (http://www.ncbi.nlm.nih. gov/BLAST) were searched using the nucleotide BLAST program. Multiple sequence alignments were performed using the CLUSTALW (http://www.genome.jp/tools/clustalw/) software. The protein structure prediction was performed using the HMMer software, version 2.2 (http://hmmer.janelia.org). Phylogenetic trees were constructed using the MEGA4 program (34).
Purification of HLB pathogen immunogen. ' $\mathrm{Ca}$. L. asiaticus'infected periwinkle midribs ( $30 \mathrm{~g})$ were ground in liquid nitrogen, then ground with $100 \mathrm{ml}$ of separation buffer $\left(0.1 \mathrm{M} \mathrm{MgCl}_{2}, 0.5 \mathrm{M}\right.$ mannitol, and $0.6 \mathrm{M}$ glycine, $\mathrm{pH}$ 7.4). The homogenate was then incubated with cellulase ( $1 \mathrm{mg}$ cellulase per milliliter of homogenate) for $3 \mathrm{~h}$ at $35^{\circ} \mathrm{C}$. Then, the mixture was filtered and centrifuged at $5,000 \times g$ for $20 \mathrm{~min}$ at $4^{\circ} \mathrm{C}$. Supernatant was further centrifuged at $35,000 \times g$ for $40 \mathrm{~min}$ at $4^{\circ} \mathrm{C}$. After that, the pellets were retained and resuspended in separation buffer. The differential centrifugation was repeated again and the pellets were resuspended in a buffer containing $0.5 \mathrm{M}$ mannitol and $30 \mathrm{mM}$ cysteine, $\mathrm{pH}$ 7.0. The suspension was kept at room temperature for $30 \mathrm{~min}$ and centrifuged at $5,000 \times g$ at $4^{\circ} \mathrm{C}$ for $20 \mathrm{~min}$, as described previously $(21,25)$. The supernatant was collected and stored at $4^{\circ} \mathrm{C}$ for further experimentation.

Table 3. Specificity of the Omp antibody for detection of 'Candidatus Liberibacter asiaticus' by indirect enzyme-linked immunosorbent assay (ELISA)

\begin{tabular}{|c|c|c|c|c|}
\hline Host & Sample types & Total number of samples & $\mathbf{P C R}^{\mathbf{a}}$ & $\mathbf{E L I S A}^{\mathbf{b}}$ \\
\hline Citrus reticulata Blanco 'Succosa' & Citrus tristeza virus & 10 & - & $0.094-0.244$ \\
\hline C. sinensis Osbeck 'Newhall' & Citrus tatter leaf virus & 5 & - & $0.192-0.259$ \\
\hline C. sinensis Osbeck 'Jincheng' & Citrus exocortis viroid & 7 & - & $0.147-0.173$ \\
\hline C. unshiu Marc. 'Miyagawa Wase' & Satsuma dwarf virus & 8 & - & $0.193-0.132$ \\
\hline C. sinensis Osbeck Newhall & Xanthomonas citri subsp. citri & 12 & - & $0.143-0.261$ \\
\hline C. unshiu Marc. Miyagawa Wase & Colletotrichum gloeosporioides & 10 & - & $0.11-0.241$ \\
\hline C. reticulata Blanco 'Ponkan' & Nitrogen deficiency & 12 & - & $0.163-0.188$ \\
\hline C. reticulata Blanco Succosa & Magnesium deficiency & 13 & - & $0.149-0.183$ \\
\hline C. sinensis Osbeck 'Hamlin' & Iron deficiency & 10 & - & $0.131-0.161$ \\
\hline C. sinensis Osbeck Hamlin & Manganese deficient & 8 & - & $0.087-0.115$ \\
\hline C. sinensis Osbeck 'Liubencheng' & Zinc deficiency & 10 & - & $0.108-0.173$ \\
\hline C. unshiu Marc. Miyagawa Wase & Boron deficiency & 7 & - & $0.098-0.144$ \\
\hline C. unshiu Marc. Miyagawa Wase & Glyphosate phytotoxicity & 15 & - & $0.161-0.172$ \\
\hline C. reticulata Blanco Ponkan & Huanglongbing ${ }^{c}$ & 6 & + & $0.503-0.633$ \\
\hline C. reticulata Blanco Ponkan & Healthy control $^{\mathrm{d}}$ & 6 & - & $0.113-0.131$ \\
\hline
\end{tabular}

a Primers used in this column were described in Materials and Methods. Positive or negative results were denoted as + or - , respectively. Samples with no visual band displayed on an agarose gel were considered negative.

${ }^{\mathrm{b}}$ Optical density at $450 \mathrm{~nm}\left(\mathrm{OD}_{450}\right.$ (sample)/OD $\mathrm{OD}_{450}$ (negative control) $>2.1$ would be considered to be a positive result. Values in this column represent the range of the $\mathrm{OD}_{450}$ (sample).

c Positive control.

d Negative control.

Table 4. Sensitivity comparison between polymerase chain reaction (PCR) and enzyme-linked immunosorbent assay (ELISA) for detection of 'Candidatus Liberibacter asiaticus' in symptomatic samples from different geographical origins and host species ${ }^{\mathrm{a}}$

\begin{tabular}{|c|c|c|c|c|}
\hline Geographical origins & Host & Total samples & PCR & ELISA \\
\hline \multicolumn{5}{|l|}{ Zhejiang Province } \\
\hline \multirow[t]{5}{*}{ Huangyan } & Citrus reticulata Blanco 'Succosa' & 32 & 15 & $13(2)$ \\
\hline & C. unshiu Marc. 'Miyagawa Wase' & 20 & 9 & 8 \\
\hline & C. reticulata Blanco 'Tardiferax' & 13 & 2 & $1(1)$ \\
\hline & C. sinensis Osbeck 'Hamlin' & 15 & 12 & $10(1)$ \\
\hline & C. reticulata $\times C$. sinensis & 7 & 4 & 4 \\
\hline Wenling & $C$. sinensis $\times C$. grandis & 12 & 8 & 7 \\
\hline Yuhuan & C. grandis Osbeck. 'Yuhanyou' & 25 & 10 & 10 \\
\hline Wenzhou & C. reticulata Blanco 'Suavissima' & 34 & 17 & $13(2)$ \\
\hline Lishui & C. reticulata Blanco 'Ponkan' & 27 & 20 & $16(2)$ \\
\hline \multicolumn{5}{|l|}{ Fujian Province } \\
\hline Pinghe & C. grandis Osbeck 'Guanximiyou' & 17 & 8 & 8 \\
\hline Yongchun & C. reticulata Blanco Ponkan & 15 & 13 & $11(3)$ \\
\hline Changle & C. reticulata Blanco 'Tangerina' & 8 & 3 & $1(1)$ \\
\hline \multicolumn{5}{|l|}{ Jiangxi Province } \\
\hline Xingfeng & C. sinensis Osbeck 'Newhall' & 7 & 5 & 4 \\
\hline Quannan & C. unshiu Marc. Miyagawa Wase & 16 & 7 & 4 \\
\hline \multicolumn{5}{|l|}{ Guangxi Province } \\
\hline Guilin & C. sinensis Osbeck 'Valencia' & 5 & 2 & 2 \\
\hline Yulin & C. grandis Osbeck 'Shatianyou' & 27 & 12 & $12(1)$ \\
\hline \multicolumn{5}{|l|}{ Guangdong Province } \\
\hline Yunfu & C. reticulata Blanco 'Shatangju' & 31 & 25 & $19(1)$ \\
\hline Zhaoqing & C. reticulata Blanco 'Gongan' & 27 & 24 & $18(3)$ \\
\hline Heyuan & C. reticulata Blanco Ponkan & 32 & 12 & 9 \\
\hline Shantou & C. reticulata Blanco 'Tankan' & 13 & 2 & 2 \\
\hline Meizhou & C. sinensis Osbeck Newhall & 11 & 3 & 2 \\
\hline Qingyuan & C. reticulata Blanco Shatangju & 24 & 22 & $17(2)$ \\
\hline Total & $\ldots$ & 418 & 235 & 191 \\
\hline
\end{tabular}

a Numbers in the table are the number of total samples or positive samples. Numbers in parentheses show differences in results obtained by ELISA and PCR assays. Primer and detection methods were similar to those in Table 3. 
Antisera preparation. New Zealand white rabbits received four injections with Omp recombinant proteins via the intramuscular route. The first injection consisted of $500 \mu \mathrm{g}$ of the recombinant proteins possessing the $\mathrm{N}$-terminal or $\mathrm{C}$-terminal region of $\mathrm{Omp}$ protein in $500 \mu \mathrm{l}$ of phosphate-buffered saline (PBS) emulsified with $500 \mu \mathrm{l}$ of Freund's complete adjuvant. The rabbits were then immunized with $250 \mu \mathrm{g}$ of the recombinant proteins in $500 \mu \mathrm{l}$ of PBS emulsified with $500 \mu \mathrm{l}$ of Freund's incomplete adjuvant in week 2, 5, and 8. Serums were collected in week 10. Prior to use, the antisera were purified, filter sterilized, and stored at $-20^{\circ} \mathrm{C}$. The polyclonal antibody against ' $\mathrm{Ca}$. L. asiaticus' was obtained using extracts from infected phloem tissues as immunogen with a similar procedure. However, in this case, the enriched pathogen was incubated for $30 \mathrm{~min}$ at $37^{\circ} \mathrm{C}$ with white rabbit antiserum prepared against the homogenates of healthy phloem tissues before immunization, as described previously (14).

Purification of Omp antibodies. Affinity chromatography columns were prepared by coupling Omp recombinant proteins to CNBr-Activated Sepharose 4B (GE Healthcare) according to the manufacturer's instructions. The immune sera diluted with an equal volume of PBS with Tween 20 (PBST, including $137 \mathrm{mM} \mathrm{NaCl}$, $2.7 \mathrm{mM} \mathrm{KCl}, 4.3 \mathrm{mM} \mathrm{Na} \mathrm{HPO}_{4} \cdot 7 \mathrm{H}_{2} \mathrm{O}, 1.4 \mathrm{mM} \mathrm{K \textrm {K } _ { 2 }} \mathrm{PO}_{4}$, and $0.05 \%$ Tween 20) were loaded into the columns and incubated for $3 \mathrm{~h}$ at room temperature. Then, the columns were washed with the same buffer and the bound antibodies were eluted in fractions with

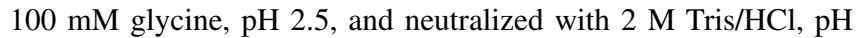
8.0. The antibody solutions were dialyzed against PBS and stored at $-70^{\circ} \mathrm{C}$ in $50 \%$ glycerol.

Indirect ELISA detection of ' $\mathrm{Ca}$. L. asiaticus' in naturally infected samples. Symptomatic leaf samples were collected in different areas by spotting trees with typical HLB symptoms. The samples were grounded with coating buffer $(0.05 \mathrm{M}$ carbonate buffer solution, $\mathrm{pH} 9.6)$ at a 1:20 (wt/vol) ratio. The optimal dilution ratio 1:20 was confirmed in serial dilution test by using the formula $1: 10 \times 2^{\mathrm{n}}(n=0,1,2,3 \ldots)$, Three independent homogenates were clarified by centrifugation at $12,000 \times g$ for $1 \mathrm{~min}$, and then $150 \mu \mathrm{l}$ of supernatant was pipetted into microplate wells in triplicate and incubated overnight at $4^{\circ} \mathrm{C}$. After washing three times with PBST, the microplate wells were blocked with $200 \mu \mathrm{l}$ of $2 \% \mathrm{BSA}$ at $37^{\circ} \mathrm{C}$ for $1 \mathrm{~h}$. The plate was washed and serially diluted antibodies $(150 \mu \mathrm{l})$ were added into each well and incubated at $37^{\circ} \mathrm{C}$ for $2 \mathrm{~h}$. After washing three times, $150 \mu \mathrm{l}$ of horseradish peroxidase-conjugated goat anti-rabbit immunoglobulin $\mathrm{G}$ (IgG) was added at a $1 / 10,000$ dilution and incubated at $37^{\circ} \mathrm{C}$ for $2 \mathrm{~h}$. The $3,3^{\prime}, 5,5^{\prime}$ tetramethylbenzidine (TMB) substrate solution was added to the wells and incubated at $37^{\circ} \mathrm{C}$ for 15 to $30 \mathrm{~min}$ for color development. After the reaction was stopped by the addition of sulfuric acid solution, the OD of each well was measured at 450 $\mathrm{nm}\left(\mathrm{OD}_{450}\right)$ in a microplate reader. Meanwhile, the PCR assay was also used to detect the pathogens in these samples (36).

Immunofluorescence microscopy. Longitudinal sections $(30 \mu \mathrm{m}$ thick) were prepared separately from healthy and infected plant midribs with a freezing microtome. Next, the sections were washed three times with $0.01 \mathrm{M}$ PBS and incubated for $30 \mathrm{~min}$ in $0.01 \mathrm{M}$ PBS with $0.3 \%$ Triton X-100, followed by washing three times with $0.01 \mathrm{M}$ PBS. They were then incubated in diluted Omp antibodies for $30 \mathrm{~min}$ followed by incubation for $45 \mathrm{~min}$ at $37^{\circ} \mathrm{C}$ in a 100 -fold dilution of fluorescein isothiocyanate (FITC)-conjugated goat antirabbit IgG. The diluted IgG solution was prepared by adding $10 \mu \mathrm{l}$ of the commercial FITC-conjugated IgG in $1 \mathrm{ml}$ of PBS solution containing $0.1 \%$ Evans blue. After washing three times with PBS, the sections were mounted in $50 \%$ glycerol and observed under a fluorescence microscope, as described previously (14). More detailed information can be found in supplementary materials.

\section{Results}

Sequences variation of $\mathrm{Omp}$ genes among ' $\mathrm{Ca}$. L. asiaticus' isolates. To characterize sequence variation of omp genes among ' $\mathrm{Ca}$. L. asiaticus' isolates from different geographical origins, 137 ' $C a$. L. asiaticus'-infected citrus samples were collected from
Zhejiang, Fujian, Guangxi, Guangdong and Jiangxi, which are major citrus-producing provinces in China. The omp nucleotide sequences were amplified with primer set OMP5/OMP3. The $о m p$ sequences of isolates in other countries mentioned in the reference (3) were also included in this experiment. DNA sequences analysis revealed that these omp sequences exhibited more than $99.9 \%$ identity among these ' $\mathrm{Ca}$. L. asiaticus' isolates, about $73 \%$ identity with omp genes of ' $\mathrm{Ca}$. L. africanus' isolates (5), and nearly $69 \%$ identity with omp genes of ' $\mathrm{Ca}$. L. solanacearum' isolates. Protein sequence alignment revealed that the Omp sequences of ' $\mathrm{Ca}$. L. asiaticus' isolates had $99.9 \%$ identities and $99.9 \%$ similarities with each other.

Analysis of suitable Omp sequence fragments for prokaryotic expression. The full-length omp gene was ligated into the pET-32a, pGEX-4T-1, or pIGH3 vector for prokaryotic expression. Unfortunately, very little recombinant protein was obtained using any of these vectors and different inducing conditions. BLAST results showed that homologues of the omp gene widely exist among prokaryotes and eukaryotes. Most of the identified homologous genes are outer membrane proteins and contain the hydrophobic POTRA domains $(4,29)$. Hammer analysis revealed statistically significant $\mathrm{E}$ values for four repeated POTRA domains in the $\mathrm{N}$ terminal regions of Omp protein at $2.9 \times 10^{-8}, 2.2 \times 10^{-6}, 1 \times 10^{-6}$, and $2.4 \times 10^{-9}(9)$. Also, the PRED-TMBB method and hydropathy plots consistently identified a $\beta$-barrel structure composed of 16 membrane-spanning $\beta$-strands on the C-terminal region of Omp $(2,24)$. On the basis of these analyses, primers OMPN5/OMPN3 and OMPC5/OMPC3 were designed to amplify the 5 -terminal POTRA and 3 -terminal $\beta$-barrel regions of the omp gene to ligate into a prokaryotic expression vector. Recombinant proteins of the $\mathrm{N}$-terminal POTRA domain of Omp (OMP-N) or C-terminal $\beta$ barrel domain of Omp (OMP-C) were successfully obtained by expressing the proteins in E. coli.

Preparation of polyclonal antibodies. The OMP-N and OMP$\mathrm{C}$, fused with His-tag, were purified (to remove E. coli cellular proteins) using nickel column chromatography. The concentrations of recombinant Omp proteins were adjusted to working concentration (described in Materials And Methods) for use as immunogens. After four injections with antigens, rabbits were bled through cardiac puncture, and the Omp antibodies were purified with affinity chromatography columns. To determine their optimal working concentration, the antibodies were serially diluted at a ratio of $1: 100 \times 2^{\mathrm{n}}(n=0,1,2,3 \ldots)$, then used to detect the pathogen in the ' $C a$. L. asiaticus'-infected citrus leaves by ELISA. The results revealed that 1:1600 dilution of the antibodies against OMP-N or OMP-C protein could produce the maximum $\mathrm{OD}_{450}$ value of positive control/OD $\mathrm{OD}_{450}$ value of negative control $(\mathrm{P} / \mathrm{N}$ value). The antibody against ' $\mathrm{Ca}$. L. asiaticus' was also produced using extracts of infected phloem tissues as immunogen, and its optimal dilution ratio was 1:800.

Detection of isolates with variation in Omp sequence as well as from different geographical origins. The antibodies against OMP-N and OMP-C or against ' $\mathrm{Ca}$. L. asiaticus' were adopted to detect ' $\mathrm{Ca}$. L. asiaticus' isolates with Omp sequence variation as well as from different geographical origins. The ELISA results showed that all three antibodies could detect ' $\mathrm{Ca}$. L. asiaticus'infected samples (Table 1). Antibodies against Omp protein had a higher $\mathrm{P} / \mathrm{N}$ ratio than the antibody against ' $\mathrm{Ca}$. L. asiaticus'. The antibody against OMP-N had the highest detection sensitivity. ' $\mathrm{Ca}$. L. asiaticus'-infected periwinkle samples detected by indirect ELISA also had a similar result but these samples usually exhibited higher absorbance at $450 \mathrm{~nm}$ than the citrus samples (Table 2).

The specificity of Omp antibodies for detection of ' $\mathrm{Ca}$. $\mathrm{L}$. asiaticus'. The specificity of antibody against OMP-N to samples infected by several viruses or viroids (Citrus tristeza virus, Citrus tatter leaf virus, Citrus exocortis viroid, and Satsuma dwarf virus) was investigated. The nutrient-deficient samples and glyphosatedamaged samples were also tested. These samples usually exhibit disease symptoms similar to those of HLB samples, which are very difficult to distinguish from one another by visual examination 
(12,16-18,20,33). In addition, samples infected with Xanthomonas citri subsp. citri and Colletotrichum gloeosporioides, which are also common pathogens of citrus, were further tested in our study. The results of this investigation showed that all of these pathogeninfected samples as well as the nutrient-deficient samples and glyphosate-damaged samples had negative results (Table 3 ). The antibody against OMP-C also had a similar result.

Comparison of sensitivity between ELISA and PCR. Sensitivity of ELISA based on Omp antibody was compared with PCR assay for detection of ' $\mathrm{Ca}$. L a asiaticus' in symptomatic citrus samples. Each sample represented a single tree and was randomly collected from the main cultivars from 18 different geographical origins in China. The result showed that the antibody against OMP-N could detect ' $\mathrm{Ca}$. L. asiaticus' in $45.7 \%$ of the symptomatic samples, and $90.05 \%$ of the detection results were consistent with the PCR assay, which could detect ' $\mathrm{Ca}$. L. asiaticus' in $56.2 \%$ of the symptomatic samples (Table 4).

In vivo detection of ' $\mathrm{Ca}$. $\mathrm{L}$. asiaticus' by immunofluorescence. The Omp antibodies were further tested for the possibility of tracking the distribution of ' $\mathrm{Ca}$. L. asiaticus' in vivo with FITClabeled secondary antibody. Strong green fluorescence was observed in the sieve tubes of ' $\mathrm{Ca}$. L. asiaticus'-infected citrus and periwinkles but not in the healthy ones, when either one of the Omp antibodies was used to treat thin sections of leaf-midribs (Fig. 1). The fluorescence was stronger on midrib sections of ' $\mathrm{Ca}$. $\mathrm{L}$. asiaticus'-infected periwinkles than on the sections of pathogeninfected citrus.

\section{Discussion}

In the present study, we describe a new HLB diagnosis method based on Omp antibodies that improves the currently used approaches, including PCR assays, to accurately detect ' $\mathrm{C} a$. L. asiaticus'. The Omp antibodies in our detection method can overcome the shortcomings of currently used antibodies. They can detect HLB pathogen strains from different geographical origins. Also, the assay procedure is more convenient and economical than earlier methods. Moreover, the Omp antibodies have potential to be used as research tools for exploring protein function and tracking distribution of HLB pathogens in citrus plants or in D. citri bodies.

At the beginning of this study, patterns of sequence variation of Omp proteins showed that these protein sequences had $99.9 \%$ identities and $99.9 \%$ similarities among the ' $\mathrm{Ca}$. L. asiaticus' isolates collected from China and several other countries (3). This indicates that ' $\mathrm{Ca}$. L. asiaticus' Omp proteins have a highly conserved protein structure in different isolates, in contrast to the former antigens that didn't have high degree of structure conservation among different isolates (13). It also suggests that Omp antibodies have the potential to detect ' $\mathrm{Ca}$. L. asiaticus' isolates from different geographical origins.

For antigen preparation, full-length Omp protein was used to express in E. coli. However, little or no recombinant protein was obtained from those recombinants. BLAST analyses revealed that most homologues of ' $\mathrm{Ca}$. L. asiaticus' omp gene are outer membrane proteins $(4,29)$. In $E$. coli, overexpressed outer membrane proteins would be degraded after triggering the $\sigma^{\mathrm{E}}$ stress response pathway (30). Therefore, it is probable that overexpressed fulllength Omp protein might also be degraded in E. coli. This prompted us to analyze the detailed structure of Omp protein in order to identify suitable Omp sequence fragments for high-level expression in E. coli. Structure analysis identified POTRA domains on the $\mathrm{N}$-terminal region and a 16-membrane-spanning $\beta$-barrel domain on the C-terminal region of Omp (5), suggesting that both of these regions possess membrane surface-exposed hydrophilic sequences that may be suitable for prokaryotic expression and antibody production $(15,37)$. On the basis of these analyses, $5^{\prime}$ terminal and 3 '-terminal regions of $o m p$ were ligated into vector to be expressed in E. coli and, finally, a large quantity of recombinant proteins were successfully obtained for immunization.

Identification of suitable Omp fragments that can be expressed at high levels in $E$. coli led to a more convenient antigen produc- tion procedure. Purification of the recombinant Omp fragments from $E$. coli with an affinity chromatography column allowed us to obtain the antigen with high purity because this method eliminates mixing of citrus proteins in the purification steps. Therefore, it can be expected that the specificity and sensitivity of Omp antibodies will be enhanced. In accordance with that calculation, the antibodies against OMP-N and OMP-C in this research were found to have a higher positive/negative ratio than the antibody against ' $\mathrm{Ca}$. $\mathrm{L}$. asiaticus', indicating that Omp antibodies have higher sensitivity in detecting the pathogen from different geographical origins (Tables 1 and 2). 'Ca. L. asiaticus'-infected periwinkle samples detected with these antibodies usually showed higher absorbance at $450 \mathrm{~nm}$ than citrus samples, suggesting that periwinkle may be a suitable, reasonably compatible host for this bacterium. Moreover, as the bioinformatics analysis had showed, the POTRA domains on the $\mathrm{N}$-terminal region of Omp protein possess higher amounts of membrane-surface-exposed hydrophilic sequences (which are poorly conserved) than the membrane-spanning $\beta$-barrel structure on the C-terminal region of Omp (5). This most likely explains why the antibody prepared from the $\mathrm{N}$-terminal region of Omp protein was more sensitive than that generated from the $\mathrm{C}$-terminal region. What's more, due to the high level of sequence conservation of ' $C a$. L. asiaticus' Omp protein, it is speculated that these Omp antibodies may also be applied to detect ' $\mathrm{Ca}$. L. asiaticus' isolates in other countries as well. Moreover, bioinformatics analysis indicates that Omp proteins of ' $\mathrm{Ca}$. L. asiaticus' and ' $\mathrm{Ca}$. L. africanus' have similar structure. Therefore, it is possible that a similar method may be used to produce the Omp antibodies of ' $\mathrm{Ca}$. L. africanus'.

The antibodies against OMP-N and OMP-C were specific to ' $\mathrm{Ca}$. L. asiaticus'. They did not show a positive signal with other common viral, bacterial, and fungal pathogens of citrus (Table 3 ). It is also free from interference of nutrient-deficient or glyphosatedamaged samples which also show symptoms similar to those of HLB pathogen-infected samples $(12,16-18,20)$. The antibody against OMP-N detects ' $\mathrm{Ca}$. L. asiaticus' in $45.7 \%$ of the sympto-

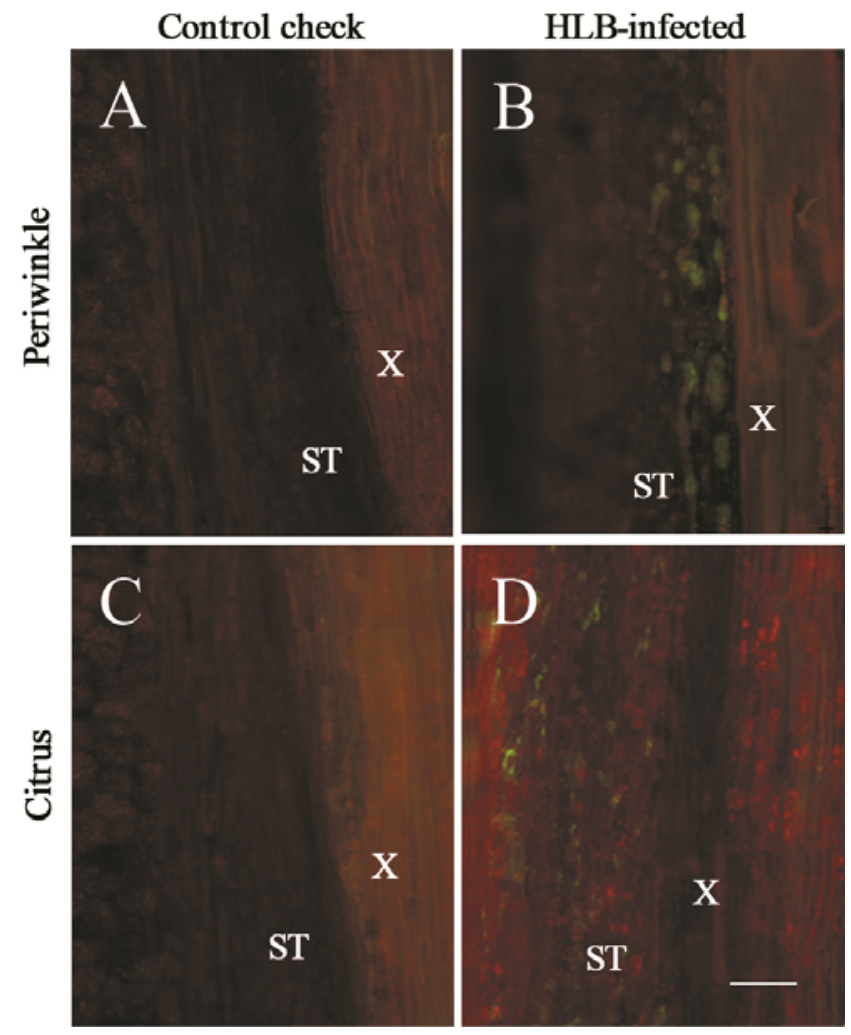

Fig. 1. Detection of 'Candidatus Liberibacter asiaticus' by immunofluorescence in midrib sections of healthy (A) and infected (B) periwinkles, in midrib sections of healthy (C) and infected (D) citrus. X, xylem; ST, sieve tube; bar $=50 \mu \mathrm{m}$. 
matic citrus samples by ELISA, which is similar to the sensitivity level obtained by traditional PCR assays (Table 4). Furthermore, ELISA is a protein-based detection method, has a different principle from PCR assays, and does not suffer from several adverse factors of citrus on DNA extraction and PCR reaction. Therefore, consensus detection results by ELISA and PCR improve the reliability of the HLB diagnosis to avoid the contradictory or ambiguous results that are prone to be provided by the single PCR detection method.

These antibodies against OMP-N and OMP-C can also be used as research tools. For example, Omp antibodies can be used in immunofluorescence to track the distribution of ' $\mathrm{Ca}$. L. asiaticus' in citrus plants (Fig. 1) or in D. citri bodies. They can also be used for studying protein-protein interactions to study the function of Omp proteins. Furthermore, the Omp antibodies can be used to produce an immunochromatographic colloid gold strip for the field detection of HLB pathogen (32). This method is not time intensive, as in the case of extracting DNA templates or processing then in highly advanced equipment. Thus it is a convenient and low-cost detection method and may be used extensively by farmers and quarantine officers.

\section{Acknowledgments}

This work was supported by the Special Fund for Agro-scientific Research in the Public Interest (201003067-08), Guangdong Modern Agricultural Technology System Fund (Yuenong-2009-380), and Taizhou Science \& Technology Planning Project Fund (091KY03) from the Chinese government.

\section{Literature Cited}

1. Albrecht, U., and Bowman, K. D. 2008. Gene expression in Citrus sinensis (L.) Osbeck following infection with the bacterial pathogen 'Candidatus Liberibacter asiaticus' causing huanglongbing in Florida. Plant Sci. 175:291306

2. Bagos, P. G., Liakopoulos, T. D., Spyropoulos, I. C., and Hamodrakas, S. J. 2004. PRED-TMBB: A web server for predicting the topology of $\beta$-barrel outer membrane proteins. Nucleic Acids Res. 32:W400-W404

3. Bastianel, C., Garnier-Semancik, M., Renaudin, J., Bové, J., and Eveillard, S. 2005. Diversity of 'Candidatus Liberibacter asiaticus', based on the omp gene sequence. Appl. Environ. Microbiol. 71:6473-6478.

4. Bos, M. P., Robert, V., and Tommassen, J. 2007. Functioning of outer membrane protein assembly factor Omp85 requires a single POTRA domain. EMBO Rep. 8:1149-1154.

5. Bové, J. M. 2006. Huanglongbing: a destructive, newly-emerging, centuryold disease of citrus. J. Plant Pathol. 88:7-37.

6. Bradford, M. M. 1976. A rapid and sensitive method for the quantitation of microgram quantities of protein utilizing the principle of protein-dye binding. Anal. Biochem. 72:248-254.

7. Bruening, G., Bové, J. M., Citron, P., Miller, P. W., Nault, L. R., Polek, M. L., Shapiro, H. Y., Shelton, A. M., Timmer, L. W., Tumlinson, J. H., and Yokomi, R. K. 2010. Strategic Planning for the Florida Citrus Industry: Addressing Citrus Greening Disease. National Academy of Sciences, National Research Council, USA.

8. Duan, Y., Zhou, L., Hall, D. G., Li, W., Doddapaneni, H., Lin, H., Liu, L., Vahling, C. M., Gabriel, D. W., and Williams, K. P. 2009. Complete genome sequence of citrus huanglongbing bacterium, 'Candidatus Liberibacter asiaticus' obtained through metagenomics. Mol. Plant-Microbe Interact. 22:1011-1020.

9. Eddy, S. R. 2011. Accelerated profile HMM searches. PLoS Comput. Biol. 7:e1002195.

10. Figenschou, D. L., Marais, J. P., and De Figueiredo, M. 2006. A comparison of three methods of nitrogen analysis for feedstuffs. S. Afr. J. Anim. Sci. 30:23-23.

11. Gao, S. J., Garnier, M., and Bove, J. M. 1993. Production of monoclonal antibodies recognizing most Asian strains of the greening BLO by in vitro immunization with an antigenic protein purified from the BLO. Pages 244249 in: Proc. 12th Conf. IOCV. IOCV, Riverside, CA.

12. Gao, Y., Zhou, C., Wang, X., Zhou, Y., and Lu, Y. 2006. RT-PCR detection of Satsum dwarf virus. Acta Phytophylac. Sin. 33:136-139.

13. Garnier, M., Gao, S. J., He, Y. L., Villechanoux, S., Gandar, J., and Bové, J. M. 1991. Study of the greening organism (GO) with monoclonal antibodies: serological identification, morphology, serotypes and purification of the GO. Pages 428-435 in: Proc. 11th Conf. IOCV. IOCV, Riverside, CA.

14. Garnier, M., Martin-Gros, G., and Bove, J. M. 1987. Monoclonal antibodies against the bacterial-like organism associated with citrus greening disease. Ann. Inst. Pasteur Microbiol. 138:639-650.

15. Gentle, I. E., Burri, L., and Lithgow, T. 2005. Molecular architecture and function of the Omp85 family of proteins. Mol. Microbiol. 58:1216-1225.
16. Gillings, M., Broadbent, P., Indsto, J., and Lee, R. F. 1993. Characterisation of isolates and strains of citrus tristeza closterovirus using restriction analysis of the coat protein gene amplified by the polymerase chain reaction. J. Virol. Methods 44:305-317.

17. Hailstones, D. L., Bryant, K. L., Broadbent, P., and Zhou, C. 2000. Detection of citrus tatter leaf virus with reverse transcription-polymerase chain reaction (RT-PCR). Australas. Plant Pathol. 29:240-248.

18. Hocquellet, A., Toorawa, P., Bove, J. M., and Garnier, M. 1999. Detection and identification of the two Candidatus Liberibacter species associated with citrus huanglongbing by PCR amplification of ribosomal protein genes of the $\beta$ operon. Mol. Cell. Probes 13:373-379.

19. Huys, G., Vanhoutte, T., Joossens, M., Mahious, A. S., De Brandt, E., Vermeire, S., and Swings, J. 2008. Coamplification of eukaryotic DNA with 16S rRNA gene-based PCR primers: possible consequences for population fingerprinting of complex microbial communities. Curr. Microbiol. 56:553557.

20. Ito, T., Ieki, H., and Ozaki, K. 2002. Simultaneous detection of six citrus viroids and Apple stem grooving virus from citrus plants by multiplex reverse transcription polymerase chain reaction. J. Virol. Methods 106:235239.

21. Ke, S., Tang, W., Gao, Q., Fan, H., and Ke, C. 1989. A preliminary study on purification of the pathogen of citrus yellow shoot and its serology. J. South China Agric. Univ. 10:1-8

22. Lopes, S. A., Frare, G. F., Bertolini, E., Cambra, M., Fernandes, N. G., Ayres, A. J., Marin, D. R., and Bové, J. M. 2009. Liberibacters associated with citrus huanglongbing in Brazil: 'Candidatus Liberibacter asiaticus' is heat tolerant, 'Ca. L. americanus' is heat sensitive. Plant Dis. 93:257-262.

23. Manjunath, K. L., Halbert, S. E., Ramadugu, C., Webb, S. E., and Lee, R. F. 2008. Detection of 'Candidatus Liberibacter asiaticus' in Diaphorina citri and its importance in the management of citrus huanglongbing in Florida. Phytopathology 98:387-396.

24. Moslavac, S., Mirus, O., Bredemeier, R., Soll, J., von Haeseler, A., and Schleiff, E. 2005. Conserved pore-forming regions in polypeptide-transporting proteins. FEBS J. 272:1367-1378.

25. Ohtsu, Y., Prommintara, M., Okuda, S., Goto, T., Kano, T., Nakashima, K., Koizumi, M., Imada, J., and Kawashima, K. 2002. Partial purification of Thai isolate of citrus huanglongbing (greening) bacterium and antiserum production for serological diagnosis. J. Gen. Plant Pathol. 68:372-377.

26. Okuda, M., Matsumoto, M., Tanaka, Y., Subandiyah, S., and Iwanami, T. 2005. Characterization of the tuf B-sec E-nus G-rpl KAJL-rpo B gene cluster of the citrus greening organism and detection by loop-mediated isothermal amplification. Plant Dis. 89:705-711.

27. Papadakis, I. E., Dimassi, K. N., and Therios, I. N.2003. Response of two citrus genotypes to six boron concentrations: concentration and distribution of nutrients, total absorption, and nutrient use efficiency. Aust. J. Agric. Res. 54:571-580.

28. Reboll, V., Cerezo, M., Roig, A., Flors, V., Lapeña, L., and García-Agustín, P. 2000. Influence of wastewater vs. groundwater on young citrus trees. J. Sci. Food Agric. 80:1441-1446.

29. Rigel, N. W., and Silhavy, T. J. 2012. Making a beta-barrel: assembly of outer membrane proteins in gram-negative bacteria. Curr. Opin. Microbiol.15:189-193.

30. Ruiz, N., and Silhavy, T. J. 2005. Sensing external stress: watchdogs of the Escherichia coli cell envelope. Curr. Opin. Microbiol. 8:122-126.

31. Schneid, A. D., Rodrigues, K. L., Chemello, D., Tondo, E. C., Ayub, M. A Z., and Aleixo, J. A. G. 2006. Evaluation of an indirect ELISA for the detection of Salmonella in chicken meat. Braz. J. Microbiol. 37:350-355.

32. Shi, C., Zhao, S., Zhang, K., Hong, G., and Zhu, Z. 2008. Preparation of colloidal gold immunochromatography strip for detection of methamidophos residue. J. Environ. Sci. 20:1392-1397.

33. Soriano, S., Netto, A. D. P., and Cassella, R. J. 2007. Determination of $\mathrm{Cu}$ $\mathrm{Fe}, \mathrm{Mn}$ and $\mathrm{Zn}$ by flame atomic absorption spectrometry in multivitamin/ multimineral dosage forms or tablets after an acidic extraction. J. Pharm. Biomed. Anal. 43:304-310.

34. Tamura, K., Dudley, J., Nei, M., and Kumar, S. 2007. MEGA4: molecular evolutionary genetics analysis (MEGA) software version 4.0. Mol. Biol. Evol. 24:1596-1599.

35. Tatineni, S., Sagaram, U. S., Gowda, S., Robertson, C. J., Dawson, W. O., Iwanami, T., and Wang, N. 2008. In planta distribution of 'Candidatus Liberibacter asiaticus' as revealed by polymerase chain reaction (PCR) and real-time PCR. Phytopathology 98:592-599.

36. Tomimura, K., Miyata, S., Furuya, N., Kubota, K., Okuda, M., Subandiyah, S., Hung, T. H., Su, H. J., and Iwanami, T. 2009. Evaluation of genetic diversity among 'Candidatus Liberibacter asiaticus' isolates collected in Southeast Asia. Phytopathology 99:1062-1069.

37. Walther, D. M., Rapaport, D., and Tommassen, J. 2009. Biogenesis of $\beta$ barrel membrane proteins in bacteria and eukaryotes: evolutionary conservation and divergence. Cell. Mol. Life Sci. 66:2789-2804.

38. Xu, C., Xia, Y., Li, K., and Ke, C. 1988. Further study of the transmission of citrus huanglongbing by a psyllid, Diaphorina citri Kuwayama. Pages 243 248 in: Proc. 10th Conf. IOCV. IOCV, Riverside, CA. 